\begin{tabular}{|c|c|c|}
\hline BIC & $\begin{array}{c}\text { BIODIK: Jurnal IImiah Pendidikan Biologi } \\
\text { ISSN 2580-0922 (online), ISSN 2460-2612 (print) } \\
\text { Volume 07, Nomor 03, Tahun 2021, Hal. 123-132 } \\
\quad \text { Available online at: } \\
\text { https://online-journal.unja.ac.id/biodik }\end{array}$ & \begin{tabular}{l|l} 
BIODIK & $(1)$
\end{tabular} \\
\hline
\end{tabular}

Research Article

open 2 Access

\title{
Apakah Model Pembelajaran Reciprocal Teaching dapat Meningkatkan Minat Belajar dan Hasil Belajar Biologi Siswa SMA?
}

\author{
(Does Reciprocal Teaching Learning Model can Increase Learning Interest and Biology Learning \\ Outcomes of High School Students)
}

\section{Shefa Dwijayanti Ramadani", Mas'udhatul Qibtiyah}

Program Studi Pendidikan Biologi,

Fakultas Keguruan dan IImu Pendidikan, Universitas Islam Madura

JI. PP Miftahul Ulum Bettet Pamekasan, Indonesia

Corresponding author: shefadwijayanti@gmail.com

\begin{tabular}{|c|c|}
\hline Informasi Artikel & ABSTRACT \\
\hline $\begin{array}{l}\text { Submit: } 18-06-2021 \\
\text { Diterima: } 30-08-2021 \\
\text { Dipublikasikan: } 29-09-2021\end{array}$ & $\begin{array}{l}\text { This study aims to investigate the effect of the Reciprocal Teaching (RT) learning } \\
\text { model on learning interest and biology learning outcomes of high school } \\
\text { students. This research was conducted through a quasi-experimental design with } \\
\text { a pretest-posttest control group design. This study involved students of tenth } \\
\text { grade of MA Miftahul Ulum Bettet Pamekasan. Two classes were taken randomly } \\
\text { each to be applied RT learning model and conventional learning. Student's } \\
\text { learning interest data were collected through the distribution of questionnaires; } \\
\text { while learning outcomes were measured through essay tests. The data obtained } \\
\text { were then analyzed using ANACOVA test with a significance level of 0.05. The } \\
\text { results showed that RT could increase student's learning interest }(p=0.034) \text { and } \\
\text { student's learning outcomes ( } p=0.000) \text {. Thus, RT can be used as alternative } \\
\text { learning model for teachers to empower students' learning interest and learning } \\
\text { outcomes. } \\
\text { Key words: learning interest, learning result, reciprocal teaching }\end{array}$ \\
\hline Penerbit & ABSTRAK \\
\hline $\begin{array}{l}\text { Program Studi Pendidikan Biologi } \\
\text { FKIP Universitas Islam Madura, } \\
\text { Jawa Timur- Indonesia }\end{array}$ & $\begin{array}{l}\text { Penelitian ini Bertujuan untuk menyelidiki pengaruh model pembelajaran } \\
\text { Reciprocal Teaching (RT) terhadap minat belajar dan hasil belajar Biologi siswa } \\
\text { SMA. Penelitian dilaksanakan melalui desain quasi eksperimen dengan } \\
\text { rancangan pretest-posttest control group design. Penelitian melibatkan siswa } \\
\text { kelas X MA Miftahul Ulum Bettet Pamekasan. Dua kelas diambil secara acak } \\
\text { masing-masing untuk diterapkan model pembelajaran RT dan pembelajaran } \\
\text { konvensional. Data minat belajar siswa dikumpulkan melalui penyebaran angket; } \\
\text { sementara hasil belajar diukur melalui tes essai. Data yang diperoleh selanjutnya } \\
\text { dianalisis menggunakan uji ANACOVA dengan nilai signifikansi sebesar } 0,05 \text {. } \\
\text { Hasil penelitian menunjukkan bahwa RT dapat meningkatkan minat belajar ( } p= \\
0,034 \text { ) dan hasil belajar siswa ( } p=0,000) \text {. Dengan demikian, RT dapat } \\
\text { digunakan sebagai alternatif pembelajaran bagi guru untuk memberdayakan } \\
\text { minat sekaligus hasil belajar siswa. } \\
\text { Kata kunci: hasil belajar, minat belajar, reciprocal teaching }\end{array}$ \\
\hline
\end{tabular}


This BIODIK : Jurnal IImiah Pendidikan Biologi is licensed under a CC BY-NC-SA (Creative Commons Attribution-ShareAlike 4.0 International License)

\section{PENDAHULUAN}

Perkembangan ilmu pengetahuan dan teknologi di era globalisasi menjadi tantangan bagi semua negara di dunia untuk meningkatkan kualitas dan mutu pendidikan. Sebagai respon yang dilakukan untuk meningkatkan mutu pendidikan di tengah tantangan global, Pemerintah Indonesia mendorong transformasi pembelajaran melalui Kurikulum 2013, sehingga pembelajaran dilaksanakan dengan berpusat pada siswa. Beberapa model pembelajaran yang disarankan dalam Kurikulum 2013 diantaranya yaitu pembelajaran berbasis penyingkapan/penelitian (discovery/ inquiry learning) maupun pembelajaran yang menghasilkan karya berbasis pemecahan masalah (project based learning) (Permendikbud 2016). Bentuk pembelajaran aktif bervariasi dan berkembang menjadi berbagai teknik/model pembelajaran, namun biasanya mengacu pada beberapa kombinasi dari aktivitas fisik atau interaksi, pemrosesan informasi secara mendalam, perencanaan aktivias pembelajaran, bertanya, pengawasan metakognitif, dan kolaborasi (Markant dkk., 2016). Penelitian sebelumnya tentang pembelajaran aktif telah mendukung peran pembelajaran aktif sebagai pendekatan yang unggul dibandingkan dengan pendekatan tradisional yang lebih memfokuskan pada penyampaian isi materi, seperti ceramah (Hartikainen et al. 2019). Potensi dan manfaat yan diberikan antara lain yaitu dapat meningkatkan motivasi dan hasil belajar siswa (Corkin, Horn, dan Pattison, 2017; Derting dan Ebert-May, 2010).

Transformasi pembelajaran yang diharapkan mampu meningkatkan kualitas pembelajaran pada kenyataannya masih berjalan lambat. Kurangnya inovasi guru untuk mencoba model-model pembelajaran yang mampu memfasilitasi siswa untuk terlibat secara aktif dalam pembelajaran masih jarang dilakukan, terutama pada sekolah-sekolah yang berada di daerah termasuk pada sejumlah sekolah di kabupaten Pamekasan. Sebagai akibatnya, siswa memiliki minat belajar yang rendah. Hasil observasi dan wawancara yang dilakukan untuk mengumpulkan informasi awal penelitian juga mengungkap bahwa kondisi tersebut berdampak terhadap perolehan hasil belajar siswa. Hal ini terungkap dari rerata nilai Ujian Tengah Semester (UTS) dan Ujian Akhir Semester (UAS) siswa pada mata pelajaran biologi kelas X semester ganjil tahun pelajaran 2019-2020 MA Miftahul Ulum Bettet yang cukup rendah, yaitu masing-masing sebesar 62 dan 65 atau berada di bawah nilai Kriteria Ketuntasan Minimal (KKM) sebesar 72. Secara keseluruhan, siswa yang bisa mencapai nilai KKM juga hanya sebesar $25 \%$ dari populasi siswa di kelas X. Pencapaian hasil belajar tersebut menggambarkan kemampuan serta kualitas siswa sebagai efek dari proses pembelajaran yang telah dijalani.

Terdapat beberapa faktor yang potensial untuk menjelaskan kondisi hasil belajar siswa yang rendah di antaranya yaitu rendahnya pengetahuan awal siswa mengenai materi biologi, kurangnya waktu dalam pembelajaran di kelas, serta minimnya sarana dan fasilitas dalam pembelajaran. Kondisi tersebut juga diperparah dengan Kegiatan Belajar Mengajar (KBM) yang masih dilaksanakan secara konvesional atau belum mengimplementasikan pembelajaran aktif. Apkarian dkk. (2021) mengklasifikasikan faktor yang mempengaruhi guru untuk tidak mengimplementasikan pembelajaran aktif menjadi dua ranah, yakni faktor umum dan faktor internal dari guru. Faktor mendasar yang dianggap membatasi pembelajaran aktif diantara yaitu ukuran kelas yang besar, penataan ruang kelas secara tradisional, serta pembelajaran yang menekankan pada hasil evaluasi. Adapun faktor yang berasal dari guru yaitu guru tidak memiliki jaminan yang layak dalam pekerjaannya (minimnya kesejahteraan pada sebagian guru), tingginya aktivitas administratif yang harus dilakukan, dan kurangnya pengalaman dalam menerapkan 
pembelajaran aktif. Atas kondisi semacam itu, maka tidak mengherankan jika masih banyak guru di sekolah yang kurang memperhatikan minat siswa dalam belajar .

Minat adalah suatu ketertarikan dan rasa suka pada sesuatu atau aktivitas tertentu, tanpa ada yang menyuruh dan cenderung untuk memberikan perhatian yang lebih besar terhadap hal atau aktivitas tersebut (Nurhasanah dan Sobandi 2016). Sejalan dengan definisi tersebut, Nuriana (2019) menjelaskan bahwa minat belajar merupakan faktor yang menumbuhkan ketertarikan atau kecenderungan pada diri siswa terhadap suatu kegiatan belajar yang dirasakan menyenangkan sehingga lama kelamaan mendatangkan kepuasan dalam dirinya. Minat mempunyai peranan yang sangat besar dalam kehidupan siswa sebab berdampak terhadap sikap dan perilakunya (Riwahyudin 2015). Siswa yang memiliki minat tinggi terhadap kegiatan pembelajaran, maka ia akan berupaya lebih keras dibandingkan dengan siswa yang memiliki minat rendah dalam belajar. Demikian pula, jika pembelajaran tidak dirancang untuk memberdayakan minat siswa, maka siswa tidak akan belajar dengan baik karena hal tersebut tidak menarik baginya.

Untuk mengatasi permasalahan tersebut, maka diperlukan upaya perbaikan melalui penerapan model pembelajaran aktif yaitu model pembelajaran pengajaran dua arah atau Reciprocal Teaching (RT). Model pembelajaran RT menekankan pada dialog antar siswa dan guru dalam memahami makna dari isi bahan bacaan (Palinscar dan Brown 1984). Reciprocal artinya suatu interaksi dimana seseorang bertindak untuk merespon yang lain, yaitu masing-masing siswa mendapat giliran untuk memimpin diskusi.

Zendler dan Reile (2018) menjelaskan bahwa pembelajaran RT didasarkan pada prinsip belajar dan pengajaran. Pengajaran RT sejalan dengan asumsi teori pembelajaran kognitif yaitu pembelajaran terjadi melalui konstruksi dan konversi struktur kognitif. Sejalan dengan penjelasan tersebut, OstovarNamaghi dan Shahhosseini dalam Mulyono, Asmawi, dan Nuriah (2018) menjelaskan bahwa dasar teori pengajaran RT yaitu zona pengembangan proksimal, pengajaran proaktif, dan scaffolding, yang berfokus pada konstruksi makna dalam proses dialogis interaksi antara guru dan peserta didik. Melalui pembelajaran semacam ini, maka peran pembelajar yaitu secara aktif memproses informasi dan mengorganisasikannya kembali; sementara guru bertindak sebagai fasilitator pembelajaran yakni memainkan peran penting dalam mempersiapkan bahan pembelajaran dan media pembelajaran, lembar kerja, dan sebagainya yang memungkinkan siswa untuk berpartisipasi aktif selama pembelajaran. Meskipun demikian, Okkinga dkk., (2018) menekankan bahwa kualitas implementasi model pembelajaran RT di kelas sangat ditentukan oleh penguasaan guru terhadap sintaks pembelajaran RT. Dengan demikian, guru perlu latihan dan penguasaan yang baik agar dapat memberikan panduan terperinci kepada siswa saat bekerja di dalam kelompok serta memberikan contoh atau pemodelan yang sesuai mengenai implementasi RT kepada siswa.

Sintaks model pembelajaran RT melibatkan empat strategi yang berkaitan dengan peningkatan pemahaman membaca dan pemantauan diri terhadap pemahaman. Keempat strategi tersebut yaitu: 1) Questioning Generating yaitu membuat pertanyaan dari suatu bahan bacaan yang dipelajari dan mencari jawabannya, 2) Clarifying yaitu mengidentifikasi hal-hal yang belum jelas dan memberikan klarifikasi atau penjelasan terutama bagi siswa yang mempunyai kesulitan dalam memahami materi pelajaran, 3) Predicting yaitu membuat hipotesis atau dugaan sementara mengenai konsep yang akan dipelajari selanjutnya, dan 4) Summarizing yaitu membuat rangkuman (ringkasan) terkait informasi-informasi penting dari konsep atau materi pembelajaran (Palinscar and Brown 1984; Carter 1997). Melalui kegiatan 
pembelajaran tersebut diharapkan siswa dapat melaksanakan pembelajaran secara aktif, kreatif dan mandiri sesuai potensi masing-masing.

Beberapa keunggulan dalam pembelajaran RT juga telah diuraikan dalam sejumlah literatur, diantaranya yaitu: (1) efektif dalam membantu siswa meningkatkan kemampuan membaca, (2) ketika terlibat dalam strategi RT, siswa berlatih mengembangkan keterampilan yang diperlukan untuk memahami dan belajar, (3) keempat strategi pembelajaran mudah dipahami dan dikuasai oleh guru maupun siswa, serta (4) interaksi yang dilakukan oleh siswa ketika memahami bahan bacaan berperan sebagai pengalaman awal bagi siswa untuk mempelajari informasi, ide, atau pengetahuan baru sebagai pondasi untuk membangun pemahamannya (Carter 1997). Sejalan dengan kelebihan model RT tersebut, (Efendi, 2013) juga memaparkan kelebihan dari model pembelajaran RT di antaranya yaitu siswa termotivasi untuk belajar serta dapat belajar mandiri.

Potensi pembelajaran RT dalam memberdayakan kemampuan dan hasil belajar juga telah dipaparkan sebelumnya oleh sejumlah peneliti. Ramadani dkk. (2015) mengungkap bahwa pembelajaran Reciprocal Teaching (RT) maupun Cooperative Script (CS) dapat meningkatkan keterampilan metakognitif, hasil belajar biologi, dan retensi hasil belajar biologi siswa SMA, termasuk pada siswa yang berakademik rendah (Ramadani, 2016). Mulyono, Asmawi, dan Nuriah (2018) melaporkan bahwa siswa yang menerapkan model pembelajaran RT menunjukkan hasil belajar matematika yang lebih tinggi dari siswa yang belajar menggunakan model lainnya yaitu Students Facilitator and Explaining setelah mengontrol kemampuan awal siswa. Hidayah, Sudarman, dan Vahlia (2019) mengungkapkan bahwa model pembelajaran RT berpengaruh terhadap hasil belajar matematika ditinjau dari kemandirian belajar. Model pembelajaran RT yang dipadukan dengan Reading Concept Map (REMAP RT) juga dapat memberdayakan keterampilan metakognitif dan hasil belajar siswa (Mar'atus, Zubaidah, dan Manahal, 2016). Demikian pula Mulyono, Asmawi, dan Nuriah (2018) melaporkan bahwa penggunaan pengajaran RT juga berdampak positif terhadap kemandirian belajar siswa.

Berdasarkan uraian tersebut, maka studi mengenai implementasi pembelajaran RT sebetulnya telah dilakukan untuk mengkaji dampaknya terhadap peningkatan kemampuan siswa. Namun sayangnya, kajian yang secara khusus menyelidiki potensi pembelajaran RT terhadap minat belajar masih belum memadai. Oleh karenanya, maka perlu dilakukan penelitian untuk menyelediki potensii Model pembelajaran RT dalam meningkatkan minat dan hasil belajar siswa pada mata pelajaran Biologi. Hasil penelitian ini akan sangat bermanfaat untuk memberikan informasi mengenai keefektivan model pembelajaran RT serta tantangannya dalam pembelajaran biologi, serta menjadi rekomendasi bagi guru dalam menerapkan model pembelajaran yang berpeluang besar dalam memberdayakan minat dan hasil belajar.

\section{METODE PENELITIAN}

Penelitian ini menggunakan desain eksperimen semu dengan rancangan pretest-posttest control group design. Penelitian dilaksanakan di MA Miftahul Ulum Bettet, Pamekasan, Jawa Timur, Indonesia. Dua kelas dipilih secara acak untuk digunakan sebagai sampel dalam penelitian. Dari kedua kelas tersebut, masing-masing dipilih satu kelas untuk diimplementasikan model pembelajaran aktif yaitu Reciprocal Teaching (RT) dan pembelajaran konvensional. Untuk mengukur minat belajar siswa digunakan angket penilaian minat belajar yang diadaptasi dari Abrantes, Seabra, dan Lages (2007). Adapun data berupa hasil belajar Biologi diukur melalui tes essai yang dikembangkan oleh peneliti. 
Instrumen tes yang dikembangkan juga telah melalui tahap uji validasi, uji daya beda, dan uji tingkat kesukaran diikuti dengan tahap revisi. Hasil uji reliabilitas pada instrumen soal tersebut yaitu sebesar 0,739 . Data minat belajar dan hasil belajar Biologi yang telah terkumpul lalu dianalisis menggunakan Uji Anakova.

\section{HASIL PENELITIAN DAN PEMBAHASAN}

Penelitian bertujuan untuk menyelidiki pengaruh model pembelajaran Reciprocal Teaching (RT) terhadap minat dan hasil belajar biologi pada siswa kelas X di MA Miftahul Ulum Bettet Pamekasan. Hasil analisis deskriptif penelitian menunjukkan bahwa perolehan rerata skor pretest dan posttest minat dan hasil belajar siswa pada kelas RT (eksperimen) lebih tinggi dibandingkan kelas konvensional (kontrol). Rerata skor pretest minat belajar siswa pada kelas eksperimen yaitu sebesar 69,95 dan posttest sebesar 89,15 ; sedangkan rerata pretest dan posttest pada kelas kontrol yaitu masing-masing sebesar 48,00 dan 72,05 (Gambar 1).

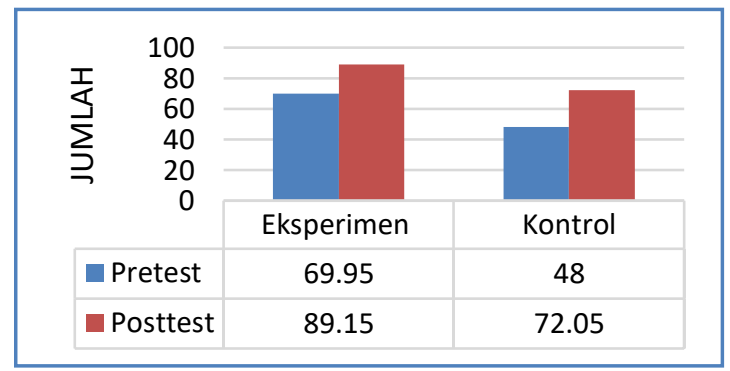

\section{Gambar 1. Rerata Skor Minat Belajar Siswa pada Kelas Eksperimen dan Kontrol}

Sejalan dengan perolehan skor minat belajar, perolehan skor pretest dan posttest hasil belajar pada kelas eksperimen yaitu masing-masing sebesar 68,85 dan 86,65 , sedangkan rerata skor pretest dan posstest pada kelas kontrol yaitu masing-masing sebesar 51, 75 dan 72,05 (Gambar 2). Berdasarkan perolehan skor tersebut, maka dapat diperoleh gambaran bahwa pada kelas eksperimen terjadi peningkatan persentase minat dan hasil belajar masing-masing sebesar $27 \%$ dan $26 \%$.

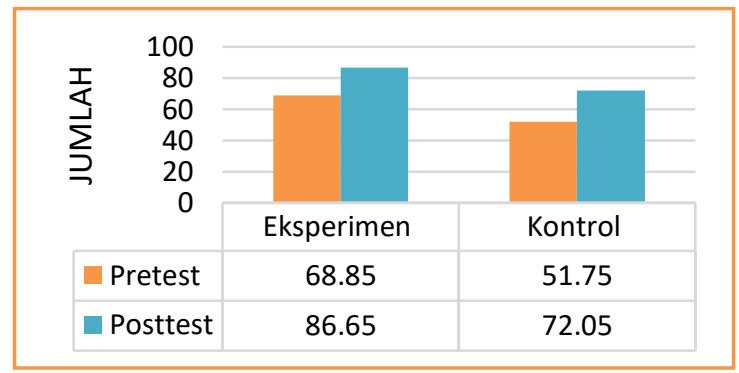

Gambar 2. Rerata Hasil Belajar Siswa pada Kelas Eksperimen dan Kontrol

Hasil analisis melalui uji Anacova terhadap minat belajar selanjutnya menunjukkan bahwa $\mathrm{F}$ hitung yang diperoleh sebesar 4, 859 dengan nilai signifikansi sebesar 0,034 $\leq 0,05$. Hal tersebut menunjukkan bahwa ada pengaruh model pembelajaran RT terhadap minat belajar siswa pada mata pelajaran biologi. Hasil tersebut juga terlihat dari skor rerata pretest dan posttest angket minat belajar siswa yang belajar melalui implementasi RT yaitu lebih tinggi dibandingkan kelas kontrol. Pada kelas yang 
mengiplementasikan RT diperoleh rerata skor pretest dan posttets masing-masing sebesar 69, 95 dan 89, 15; sedangkan pada kelas kontrol diperoleh rerata pretest dan postest masing-masing sebesar 48,00 dan 72, 05. Hasil penelitian ini rupanya sejalan dengan penelitian oleh Nuriana (2019) dan Haerini, Fauzan, dan Bernard (2019) yang menyatakan bahwa ada pengaruh model pembelajaran RT terhadap minat belajar siswa

Sejalan dengan hasil analisis di atas, hasil uji Anacova terhadap hasil belajar menunjukkan bahwa F hitung yang diperoleh sebesar 14,935 dengan nilai signifikan sebesar $0,000 \leq 0,05$. Hal tersebut mengindikasikan bahwa ada pengaruh model pembelajaran RT terhadap hasil belajar siswa. Hasil tersebut juga terlihat dari rerata skor pretest dan posttest hasil belajar siswa yang lebih tinggi pada pada kelas yang menerapkan pembelajaran RT. (Gambar 2). Hasil Penelitian ini mendukung temuan penelitian sebelumnya bahwa model pembelajaran RT dapat meningkatkan pencapaian kemampuan akademik siswa, termasuk hasil belajar Biologi (Efendi, 2013; Ramadani, Corebima, dan Zubaidah 2013; Nisa, Setiati, dan Ridlo, 2016).

Minat belajar adalah kecenderungan diri seorang siswa atau faktor yang menimbulkan ketertarikan pada suatu pembelajaran yang dirasa nyaman kemudian mendatangkan kepuasan dalam dirinya. Minat belajar dapat dipengaruhi oleh keluarga, sekolah, pergaulan antar teman dan masyarakat (Herlina dan Mustika, 2018). Temuan dalam penelitian ini memberikan gambaran bahwa model pembelajaran RT tidak hanya meningkatkan minat namun juga hasil belajar siswa. Hal ini sejalan dengan kajian empiris mengenai minat belajar yang menunjukkan hasil konsisten bahwa minat belajar dapat mempengaruhi hasil belajar (Renninger dkk., 2014). Hasil belajar akan berubah lebih baik jika minat belajar juga meningkat, maka untuk meningkatkan hasil belajar perlu adanya suatu peningkatan terhadap minat belajar.

Menurut Siregar, Hasibuan, dan Atifah (2017) model pembelajaran RT dapat melatih keterampilan metakognitif dengan menciptakan pengalaman belajar yang menyenangkan melalui pemodelan perilaku tertentu. Model RT juga dapat membantu siswa mengembangkan keterampilan tersebut berdasarkan usaha siswa itu sendiri dengan dukungan dan semangat dari sistem scaffolding. Metode scaffolding dapat memberikan pengalaman yang berkesan dan menyenangkan pada saat pelajaran berlangsung, sehingga dapat memicu minat belajar siswa selama pembelajaran dikelas. Nuriana (2019) dalam hal ini juga berpendapat bahwa model pembelajaran RT secara efektif dapat mempengaruhi peningkatan minat belajar siswa.

Aspek penting lain yang perlu diperhatikan dalam pembelajaran yaitu pencapaian hasil belajar siswa. Hasil belajar merupakan suatu predikat yang di dapat oleh siswa dari hasil interaksinya dengan guru setelah mengikuti pembelajaran. Menurut Palinscar dan Brown (1984) model pembelajaran RT mempunyai tujuan untuk mendorong siswa untuk belajar secara mandiri agar dapat mengembangkan serta meningkatkan kemampuannya. Model pembelajaran RT diterapkan melalui empat strategi mendasar yaitu summarizing, questioning generating, predicting, dan clarifying. Keempat sintaks tersebut saling berkontribusi terhadap peningkatan minat maupun hasil belajar siswa.

Aktivitas pertama yang dapat merangsang minat dan perkembangan kognitif siswa yaitu diperoleh melalui kegiatan membaca yang dilanjutkan dengan kegiatan meringkas. Aktivitas membaca dan merangkum dapat membantu siswa untuk memahami dan mengingat materi pembelajaran dengan baik jika pemahaman siswa telah baik (Efendi, 2013). Melalui kegiatan meringkas, siswa akan didorong untuk menganalisis dan membedakan informasi penting dalam suatu bacaan untuk disusun menjadi suatu ringkasan. Menurut MacKenzie dan Gardner (2006) ketika siswa membaca, siswa mengalami proses 
berpikir untuk memahami ide-ide penting serta gagasan pada suatu bahan bacaan, sehingga erat kaitannya dengan hasil belajar kognitif yang diperolehnya. Hal tersebut sejalan dengan pendapat Livingston (1997) bahwa membuat ringkasan akan meningkatkan pemahaman siswa sehingga mengarah pada peningkatan hasil belajar.

Sintaks kedua dari model pembelajaran RT yaitu questioning generating. Pada tahap ini siswa diberikan kesempatan untuk mengidentifikasi informasi-informasi yang cukup bermakna untuk dijadikan bahan pertanyaan. Melalui bertanya siswa dapat terlibat dalam aktivitas kognitif yang lebih bermakna untuk menumbuhkan minat belajarnya (Aflalo, 2021). Ahmad dan Tambak (2017) juga menegaskan bahwa minat belajar sangat erat hubungannya dengan proses tanya jawab, karena pada proses ini peserta didik dapat menumbuhkan kemampuan berpikir kreatif dan sistematis sehingga dapat menumbuhkan minat belajar dan hasil belajar berdasarkan pengetahuan baru yang diperoleh dalam proses pembelajaran.

Aktivitas bertanya juga berkontribusi terhadap perolehan hasil belajar yang lebih baik. Hal ini dijelaskan oleh Banikowski dan Mehring (1999) bahwa bertanya merupakan cara efektif untuk menstimulasi interaksi, berpikir, dan belajar. Aktivitas bertanya juga telah banyak dibicarakan terkait dengan potensinya dalam memberdayakam keterampilan berpikir, termasuk keterampilan metakognitif (Ramadani, Corebima, dan Zubaidah, 2013). Pada saat siswa mengajukan pertanyaan, maka siswa akan berupaya untuk memonitor pemahaman atas materi yang telah dipelajari, kemudian malakukan selfquestioning untuk meninjau sejauh mana dirinya mampu memahami materi yang dipelajari. Kondisi ini sangat penting dalam meningkatkan hasil belajar siswa karena siswa akan berusaha untuk memperbaiki kelemahan-kelemahan dalam belajarnya melalui penerapan strategi belajar yang sesuai.

Sintaks model pembelajaran RT yang ketiga, yaitu membuat prediksi. Strategi ini merupakan aktivitas siswa dalam mengajukan hipotesis atau perkiraan mengenai konsep atau materi yang didiskusikan (Palinscar dan Brown, 1984). Menjawab hipotesis atau prediksi melaui diskusi dengan teman sekelompok akan menambah minat siswa dalam belajar. Hal ini sejalan dengan penelitian yang dilakukan oleh Irwan (2018) bahwa penggunaan metode diskusi kelompok dapat meningkatkan minat belajar siswa.

Peningkatan hasil belajar yang diperoleh siswa pada penerapan Model pembelajaran RT juga terjadi pada saat siswa membuat prediksi atas pertanyaan yang telah dibuat. Palincsar dan Herrenkohl (2002) menjelaskan bahwa aktivitas memprediksi menggambarkan adanya keterpaduan antara pengetahuan awal dengan pengetahuan yang sedang dipelajari oleh siswa. Dengan kata lain, pada saat membuat prediksi siswa juga mengaktifkan kembali pengetahuan awal yang telah dimiliki untuk membuat jawaban sementara dari suatu permasalahan.

Strategi terakhir dari model pembelajaran RT adalah membuat klarifikasi jawaban. Menurut Palinscar dan Brown (1984) klarifikasi merupakan aktivitas penting saat pembelajaran, terutama bagi siswa yang memiliki kesulitan dalam memahami suatu materi. Melalui kegiatan membuat klarifikasi atas jawaban pertanyaan pada tahapan sebelumnya, siswa akan didorong untuk mengatasi kebingungannya dengan membaca kembali bahan bacaan. Selain itu, siswa juga dapat mengklarifikasi konsep dengan mangajukan pertanyaan siswa lainnya dalam kelompok maupun kepada guru. Menurut Ahmad dan Tambak (2017) pada saat proses tanya jawab guru dengan siswa dapat meningkatkan minat siswa dalam belajar. Di samping itu, proses mental yang dilakukan selama kegiatan ini juga mendorong pemahaman yang lebih baik sehingga hasil belajar yang diperoleh juga meningkat.

Berdasarkan uaraian di atas, maka keempat strategi dalam pembelajaran RT berkontribusi besar dalam meningkatkan minat dan hasil belajar siswa selama pembelajaran. Sebagai konsekuensinya, 
siswa yang selama ini masih mempelajari Biologi dengan situasi pembelajaran tradisional, yaitu dengan jalan menghafal atau mendengarkan ceramah dari guru, selayaknya untuk segera menerapkan model pembelajaran RT sebagai model pembelajaran aktif yang terbukti mampu memberdayakan minat dan hasil belajar siswa.

\section{SIMPULAN}

Berdasarkan uraian yang telah dipaparkan sebelumnya, maka dapat ditarik kesimpulan yaitu: (1) ada pengaruh yang signifikan antara model pembelajaran RT dengan minat belajar siswa $(p=0,034) ;(2)$ ada pengaruh yang signifikan antara model pembelajaran RT dengan hasil belajar $(p=0,000)$. Atas dasar temuan ini, maka direkomendasikan kepada guru di sekolah untuk menerapkan model pembelajaran yang melibatkan siswa secara aktif; guru perlu memperhatian kebutuhan siswa, termasuk mendesain pembelajaran yang menyenangkan untuk meningkatkan minat siswa; demikian pula penelitian ini merekomendasikan model pembelajaran RT sebagai model pembelajaran aktif yang berpotensi besar dalam meningkatkan minat dan hasil belajar siswa.

\section{RUJUKAN}

Abrantes, José Luís, Cláudia Seabra, and Luís Filipe Lages. (2007). "Pedagogical Affect, Student Interest, and Learning Performance." Journal of Business Research 60 (9): 960-64. https://doi.org/10.1016/j.jbusres.2006.10.026.

Aflalo, Ester. (2021). "Students Generating Questions as a Way of Learning." Active Learning in Higher Education 22 (1): 63-75. https://doi.org/10.1177/1469787418769120.

Ahmad, M. Y., and S. Tambak. (2017). "Hubungan Metode Tanya Jawab Dengan Minat Belajar Peserta Didik Pada Mata Pelajaran Pendidikan Agama Islam." Jurnal Pendidikan Agama Islam Al-Thariqah 2 (1): 89-110.

Apkarian, Naneh, Charles Henderson Id, Marilyne Stains, and Jeffrey Raker Id. (2021). "What Really Impacts the Use of Active Learning in Undergraduate STEM Education ? Results from a National Survey of Chemistry , Mathematics , and Physics Instructors," 1-15. https://doi.org/10.1371/journal.pone.0247544.

Banikowski, A. K., and T. A Mehring. (1999). "Strategies to Enhance Memory Based on Brain-Research." Focus on Exceptional Children 32 (2): 1-16.

Carter, C. J. (1997). "Why Reciprocal Teaching?” Educational Leadership 54: 64-69.

Corkin, Danya M, Catherine Horn, and Donna Pattison. (2017). "The Effects of an Active Learning Intervention in Biology on College Students ' Classroom Motivational Climate Perceptions , Motivation , and Achievement." Educational Psychology 3410 (May): 0. https://doi.org/10.1080/01443410.2017.1324128.

Derting, Terry L., and Diane Ebert-May. (2010). "Learner-Centered Inquiry in Undergraduate Biology: Positive Relationships with Long-Term Student Achievement." CBE Life Sciences Education 9 (4): 462-72. https://doi.org/10.1187/cbe.10-02-0011.

Efendi, N. (2013). "Pengaruh Pembelajaran Reciprocal Teaching Dipadukan Think Pair Share Terhadap Peningkatan Kemampuan Metakognitif Belajar Biologi Siswa SMA Berkemampuan Akademik Berbeda Di Kabupaten Sidoarjo." Jurnal Santiaji Pendidikan (JSP) 3 (2): 85-109.

Efendi, Nur. (2013). "Pengaruh Pembelajaran Reciprocal Teaching Dipadukan Think Pair Share Terhadap Peningkatan Kemampuan Metakognitif Belajar Biologi Siswa SMA Berkemampuan 
Akademik Berbeda Di Kabupaten Sidoarjo." Jurnal Santiaji Pendidikan 3 (2): 85-109.

Haerini, R., G. A. Fauzan, and M. Bernard. (2019). "Penerapan Model Pembelajaran Reciprocal Teaching Untuk Meningkatkan Minat Belajar Siswa Smp Di Era Teknologi." JPMI (Jurnal Pembelajaran Matematika Inovatif) 2 (5): 229-36.

Hartikainen, Susanna, Heta Rintala, Laura Pylväs, and Petri Nokelainen. (2019). "The Concept of Active Learning and the Measurement of Learning Outcomes: A Review of Research in Engineering Higher Education." Education Sciences 9 (4): 9-12. https://doi.org/10.3390/educsci9040276.

Herlina, M., and M. Mustika. (2018). "Pengaruh Model Pembelajaran Reciprocal Teaching Menggunakan Mind Mapping Terhadap Minat Dan Hasil Belajar Siswa SMA Negeri 6 Rejang Lebong." Jurnal Kependidikan 2 (2): 12-19.

Hidayah, Laila, S. W. Sudarman, and Ira Vahlia. (2019). "Pengaruh Model Pembelajaran Reciprocal Teaching Terhadap Hasil Belajar Matematika Ditinjau Dari Kemandirian Belajar." Aksioma 8 (1): 237-47.

Irwan, I. (2018). "Penerapan Metode Diskusi Dalam Peningkatan Minat Belajar." IQRO: Journal of Islamic Education 1 (1): 43-54.

Livingston, J a. (1997). "Metacognition: An Overview." Psychology 13: 259-266. http://gse.buffalo.edu/fas/shuell/CEP564/Metacog.htm.

Mackenzie, A. H., and A. Gardner. (2006). "Beyond the Lab Report: Why We Must Encourage More Writing in Biology." The American Biology Teacher 68 (6): 325-27.

Mar'atus, Sholihah, Siti Zubaidah, and Susriyati Manahal. (2016). "Memberdayakan Keterampilan Metakognitif Dan Hasil Belajar Kognitif Siswa Dengan Model Pembelajaran Reading Concept MapReciprocal Teaching (REMAP RT)." Jurnal Pendidikan 1 (4): 628-33.

Markant, Douglas B., Azzurra Ruggeri, Todd M. Gureckis, and Fei Xu. (2016). "Enhanced Memory as a Common Effect of Active Learning." Mind, Brain, and Education 10 (3): 142-52. https://doi.org/10.1111/mbe.12117.

Mulyono, Dodik, Moch Asmawi, and Tuti Nuriah. (2018). "The Effect of Reciprocal Teaching, Student Facilitator and Explaining and Learning Independence on Mathematical Learning Results by Controlling the Initial Ability of Students." International Electronic Journal of Mathematics Education 13 (3): 199-205. https://doi.org/10.12973/iejme/3838.

Nisa, Z., N. Setiati, and S Ridlo. (2016). "Efektivitas Pembelajaran Reciprocal Teaching Terhadap Aktivitas Dan Hasil Belajar Siswa Materi Protista." Journal of Biology Education 5 (3): 261-70.

Nurhasanah, Siti, and A. Sobandi. (2016). "Minat Belajar Sebagai Determinan Hasil Belajar Siswa." Jurnal Pendidikan Manajemen Perkantoran 1 (1): 128. https://doi.org/10.17509/jpm.v1i1.3264.

Nuriana, P. F. D. (2019a). Pengaruh Model Pembelajaran Reciprocal Teaching Terhadap Minat Dan Hasil Belajar Matematika Siswa Kelas VII Mts Al Maarif Tulungagung Pada Materi Bentuk Aljabar. Tulungagung: Institut Agama Islam Negeri Tulungagung.

Okkinga, Mariska, Roel van Steensel, Amos J.S. van Gelderen, and Peter J.C. Sleegers. (2018). "Effects of Reciprocal Teaching on Reading Comprehension of Low-Achieving Adolescents. The Importance of Specific Teacher Skills." Journal of Research in Reading 41 (1): 20-41. https://doi.org/10.1111/1467-9817.12082.

Palincsar, A. S., and L. R. Herrenkohl. (2002). "Designing Collaborative Learning Contexts." Theory into Practice 41 (1): 26-32.

Palinscar, Aannemarie Sullivan, and Ann L. Brown. (1984). "Reciprocal Teaching of Comprehension- 
Fostering and Comprehension-Monitoring Activities." Cognition and Instruction 1 (2): 117-75.

Permendikbud. (2016). Peraturan Menteri Pendidikan dan Kebudayaan Nomor 22 Tahun 2016 Tentang Standar Proses Pendidikan Dasar dan Menengah.

Pintrich, Paul. (2004). "A Conceptual Framework for Assessing Motivation and SRL in College Students." Educational Psychology Review 16 (4): 385-407.

https://deepblue.lib.umich.edu/bitstream/handle/2027.42/44454/10648_2004_Article_NY00000604 .pdf;jsessionid=84C5931C2B16127B3BB6CD5DC43C8B0F?sequence=1.

Ramadani, S. D. (2016). "Perbandingan Potensi Strategi Pembelajaran Reciprocal Teaching Dan Cooperative Script Dalam Memberdayakan Retensi Siswa." Wacana Didaktika 4 (2): 171-82.

Ramadani, S. D., A. D. Corebima, and S. Zubaidah. (2013). Perbandingan Potensi Strategi Pembelajaran Reciprocal Teaching (RT) dan Cooperative Script (CS) dalam Memberdayakan Keterampilan Metakognitif, Hasil Belajar Biologi, Dan Retensi Pada Siswa Berkemampuan Akademik Rendah. SKRIPSI Jurusan Biologi-Fakultas MIPA UM.

Ramadani, S. D, A. Fauzi, I. Sukmawati, and A. D. Corebima. (2015). "Ramadani, S. D., Fauzi, A., Sukmawati, I., \& Corebima, A. D. (2015). Perbandingan Potensi Strategi Pembelajaran Cooperative Script Dan Reciprocal Teaching Dalam Memberdayakan Keterampilan Metakognitif, Hasil Belajar Biologi, Dan Retensi Siswa SMA." In Proceedings of the 2nd Seminar \& Workshop Nasional Biologi, IPA, Dan Pembelajarannya FMIPA UM.

Renninger, K. A., S. Hidi, A. Krapp, and A. Renninger. (2014). The Role of Interest in Learning and Development. Psychology Press.

Riwahyudin, Arvi. (2015). "Pengaruh Sikap Siswa dan Minat Belajar Siswa Terhadap Hasil Belajar IPA Siswa Kelas V Sekolah Dasar di Kabupaten Lamanda." Jurnal Pendidikan Dasar 6 (1): 11-23.

Siregar, E., I. S. Hasibuan, and Y. Atifah. (2017). "Penerapan Model Reciprocal Teaching Dengan Game Smart Case Untuk Meningkatkan Minat Belajar Biologi Di SMA Negeri 1 Angkola Timur." Jurnal PeTeKa 1 (1): 35-36.

Zendler, Andreas, and Swetlana Reile. (2018). "The Effect of Reciprocal Teaching and Programmed Instruction on Learning Outcome in Computer Science Education." Studies in Educational Evaluation 58 (December 2017): 132-44. https://doi.org/10.1016/j.stueduc.2018.05.008. 